\title{
Breastfeeding in Mother to Child Transmission in HIV Patient in West Java
}

\author{
Anggraini Alam ${ }^{1}$, Riyadi Riyadi ${ }^{1}$, Filla Reviyani Suryaningrat ${ }^{1}$, Yanti Siauta ${ }^{1}$, Yelliantty Yelliantty ${ }^{2}$ \\ ${ }^{1}$ Department of Pediatrics-Hasan Sadikin General Hospital, Universitas Padjadjaran, Bandung, West Java, Indonesia \\ ${ }^{2}$ Department of Food Technology, Pasundan University, Bandung, Indonesia
}

Email address:

anggialam@yahoo.co.id (A. Alam)

\section{To cite this article:}

Anggraini Alam, Riyadi Riyadi, Filla Reviyani Suryaningrat, Yanti Siauta, Yelliantty Yelliantty. Breastfeeding in Mother to Child Transmission in HIV Patient in West Java. American Journal of Pediatrics. Vol. 2, No. 4, 2016, pp. 15-18. doi: 10.11648/j.ajp.20160204.11

Received: July 1, 2016; Accepted: November 5, 2016; Published: December 10, 2016

\begin{abstract}
Estimates and projections of children living with HIV, the number of new HIV infections and AIDS-related deaths show an increasing trend every year. The number of children living with HIV is projected increase from 20,181 in 2014 to 31,146 in 2019, and the projected number of new infections in this age will increase from 4,653 in 2014 to 5,309 in 2019. On the other hand, the estimated number and projections of AIDS-associated deaths in children will change from 2,107 in 2014 to 2,950 in 2019. The objective of this study is to identify one of risk factor in HIV transmission from mother to child, which is breastfeeding and enrich the knowledge related to risk factors of HIV transmission from mother to child, so that the transmission rate can be reduce. This study was a case-control design conducted in the Hasan Sadikin General Hospital, Bandung. From 2002 until 2010. Subjects were all children, from 6-14 years old which are carried out the HIV test. Two groups were observed. First group were children with HIV positive and control group were HIV negative children with HIV positive mother. Data on breastfeeding history was obtained from interviews with family. The whole pregnant and lactating women have not been taking ART. One hundred and twenty-eight children were included in the analysis. There was more male (59\%) than female children (41\%). There were 68 HIV positive children in the case group and 60 children in the control group. Main delivery method in both case and control group was vaginal birth (75\% and 52\%). Breastfeeding was much higher in case group ( $88 \%$ vs $52 \%$ ). Association between HIV infection in children and delivery method is not significant. On the other hand, breastfeeding is significantly associated with HIV infection in children. Children who were breastfed are twelve times ( $95 \%$ CI $3.275-62.981$ ) more likely to have HIV infection. It was concluded that breastfeeding is an important risk factor in HIV transmission from mother to child, when mothers had had no ARV therapy.
\end{abstract}

Keywords: Breastfeeding, HIV, Transmission

\section{Introduction}

Human Immunodeficiency Virus (HIV) is the virus that causes AIDS, which included in a group of retroviruses. A person, who has got infected by HIV, will get infected for their lifetime. Most people with HIV / AIDS remain asymptomatic (without signs and symptoms of a disease) for a long period. However, in fact, during the period there is still an opportunity for them to infect others. ${ }^{1}$

In 2010 there was an estimation of 57,000 pregnant women, who have got infected by HIV in Southeast Asia. Countries with a high burden of HIV infection that transmitted from mother to child, including Indonesia showed the estimated incidence of HIV among pregnant women is likely to remain the same for five years.

Less than one per cent of pregnant women were tested for HIV in 2008. In 2011, only 15.7 per cent of pregnant women living with AIDS received ARV to reduce mother to child transmission. The proportion of women in new HIV infections in Indonesia has grown from 34 per cent in 2008 to 44 per cent in 2011 (HIV data from Ministry of Health, Progress Report HIV \& AIDS Situation in Indonesia up to December 2011). The Ministry of Health has projected a rise in infections among children, as new HIV infections increase among women. Risk of HIV transmission from mother to 
baby is at $15-35 \%$, with the lowest figure is reported in Europe and the highest is in Africa.

Moreover, Indonesia has been known as one of the countries with fastest growing of HIV / AIDS in Asia (UNAIDS, 2008) and also known as a country with a concentrated HIV epidemic, because there are some areas where the prevalence of HIV more than $5 \%$ in subpopulations particular, and the prevalence HIV in the general population 15-49 years occurred in the province of Papua and West Papua (2.4\%).

Prevention of HIV Transmission from Mother to Child (PHTMC) has proven to be highly effective interventions to improve maternal and child health. In developed countries the risk of transmission from mother to child can be reduced to be less than $2 \%$ for PHTMC services provided and implemented optimally. However, in developing countries or poor countries, with a lack of access to services, the risk of transmission ranges from $25 \%-45 \%$. The estimated number of new HIV infections (x1000) during pregnancy, during childbirth and while breastfeeding are $38.1 \%, 39.0 \%$, and $37.4 \%$, respectively. With this background, the study aims to identify one of risk factor, which is breastfeeding, so the knowledge related to risk factors of HIV transmission from mother to child can be enriched.

\section{Methods}

This study was a case-control design conducted in the Hasan Sadikin General Hospital, Bandung. From 2002 until 2010. Subjects were all children, from 6-14 years old which are carried out the HIV test. Two groups were observed. First group were children with HIV positive and control group were HIV negative children with HIV positive mother. Data on breastfeeding history was obtained from interviews with family. The whole pregnant and lactating women have not been taking ART.

Based on the subject collection, total subjects were 128 subjects, with details of 68 subjects in the HIV group, treated at Hasan Sadikin Hospital, with a history of exposure to risk factors records and 60 subjects in the group of non-HIV. Data was analyzed, frequencies were reported for categorical variables. Bivariate logistic regression was conducted to model HIV infection in babies against risk factors. Odds ratios, 95\% confidence intervals, and p-values were noted. Any variable with a $\mathrm{p}$-value of $<0.2$ in the bivariate logistic regression model was included in the multivariable model. This study has received permission from the Ethics Committee of Hasan Sadikin Hospital.

\section{Results}

\subsection{Study Sample}

Study sample is available in Table 1. One hundred and twenty eight babies were included in the analysis. There was more male babies $(59 \%)$ than female babies $(41 \%)$. There were 68 HIV positive babies in the case group and 60 babies in the control group. Main delivery method in both case and control group was vaginal birth (75\% and 52\%). Breastfeeding was much higher in case group ( $88 \%$ vs $52 \%$ ).

\subsection{Bivariate Analysis}

Bivariate logistic regression analysis of HIV infection in babies against sex, delivery method, and breastfeeding are shown in Table 2. Significant positive associations were observed between HIV infection in babies and delivery method (OR 2.806; 95\% CI 1.344-6.017) and breastfeeding (OR 7.016; 95\% CI 2.982-18.162). Breastfeeding and delivery method were included in multivariate logistic regression.

\subsection{Multivariate Analysis}

Association between HIV infection in babies and delivery method is not significant. On the other hand, breastfeeding is significantly associated with HIV infection in babies. Babies who were breastfed are twelve times (95\% CI 3.275 $62.981)$ more likely to have HIV infection.

Table 1. Characteristics of Subjects.

\begin{tabular}{llll}
\hline Subject Characteristics & HIV+(N: 68) & HIV-(N: 60) & Total (N: 128) \\
\hline Sex & & & \\
Male & $39(57 \%)$ & $37(62 \%)$ & $76(59 \%)$ \\
Female & $29(43 \%)$ & $23(38 \%)$ & $52(41 \%)$ \\
Type of delivery & & & \\
Pervaginam & $51(75 \%)$ & $31(52 \%)$ & $82(64 \%)$ \\
Sectiocaesaria & $17(25 \%)$ & $29(48 \%)$ & $46(36 \%)$ \\
Breastfeeding & & & \\
Yes & $60(88 \%)$ & $31(52 \%)$ & $91(71 \%)$ \\
No & $8(12 \%)$ & $29(48 \%)$ & $37(29 \%)$ \\
\hline
\end{tabular}

Table 2. Bivariate logistic regression.

\begin{tabular}{lcc}
\hline Variable & Crude OR (95\% CI) & P-value \\
\hline $\begin{array}{l}\text { Sex } \\
\text { Male vs Female } \\
\text { Type of delivery }\end{array}$ & $1.196(0.590-2.442)$ & 0.620 \\
$\begin{array}{l}\text { Vaginal birth vs Caesarean } \\
\text { Breastfeeding }\end{array}$ & $2.806(1.344-6.017)$ & 0.007 \\
Yes vs No & $7.016(2.982-18.162)$ & 0.000 \\
\hline
\end{tabular}

Table 3. Multivariate logistic regression.

\begin{tabular}{lll}
\hline Variable & Adjusted OR (95\% CI) & P-value \\
\hline $\begin{array}{l}\text { Type of delivery } \\
\text { Vaginal birth vs Caesarean }\end{array}$ & $0.499(0.108-1.705)$ & 0.307 \\
$\begin{array}{l}\text { Breastfeeding } \\
\text { Yes vs No }\end{array}$ & $12.377(3.275-62.981)$ & 0.001 \\
\hline
\end{tabular}

\section{Discussion}

Generally, transmission of HIV from mother to child HIV can occur during pregnancy, during delivery or during breastfeeding. Without intervention, the risk of HIV transmission from mother to child reported to range between $15-45 \%$. The risk of transmission is higher compared to developed countries, which was reported to be about $14-26 \%$. Most reported transmission that occurs is during intrapartum period. In women who are not giving breastfeed. $24-40 \%$ 
intrauterine transmission occurs and $60-75 \%$ occurs during intrapartum period or during early lactation and $10-15 \%$ are during delivery. The risk of intrauterine, intrapartum and postpartum is $6 \%, 18 \%$ and $4 \%$, respectively, from all births to HIV-positive mothers.

Among these factors, the levels of HIV in the mother during labor or during labor is also one of the most important predictor. PACTGA 185 indicated the number $<500$ copies / $\mathrm{mL}$. Garcia et al showed $21 \%$ of these infections were in women with HIV levels of $<100,000 / \mathrm{mL}$, whereas at levels $>100,000 / \mathrm{mL}$ transmissions occurred $63 \%$. Jiohn et al find transmission four times higher in mothers with HIV levels $>43,000$ copies / $\mathrm{mL}>$ However, HIV levels which are low or undetectable levels does not guarantee that the baby will not be infected because in some cases the transmission process still persists. In addition, levels of maternal HIV before and during labor will also determine the levels of transmitted HIV in children. Wiener suggested a linear relationship between HIV levels in maternal and HIV levels in infant during the first 3 months of life.

Up to now, the diagnosis of HIV infection in children who were born from HIV positive mothers is quite difficult to do. This difficulty happened due to HIV transmission that can occur in some time, ie during pregnancy, particularly the third trimester, during childbirth and during lactation. Unfortunately, until now no studies that examine the detection of HIV infection in the womb. In addition, the window period after a person is infected with HIV that can last up to 6 months. At this time, HIV has existed in the body, but because the body is not enough to form antibodies, the HIV test led to the presence of HIV antibodies will give test results of a false negative. Therefore, this study included HIV-infected children after the age of 18 months, or had done PCR DNA / RNA.

If the mother did not breastfeed her baby, the risk of HIV transmission to be $20-30 \%$ and will be reduced if the mother would get ARV treatment. Giving ARV short-term and exclusive breastfeeding has the risk of HIV transmission by $15-25 \%$ and the risk of transmission by $5-15 \%$ respectively, if the mother was not giving breastfeed. However, with longterm antiretroviral therapy (ART), the risk of HIV transmission from mother to child can be reduced further to $1-5 \%$, and mothers who breastfeed exclusively has the same risk of transmitting HIV to their children than mothers who did not breastfeed. By the good PHTMC, then the transmission rate can be reduced to less than $2 \%$.

Breast milk has been known to contain HIV in a considerable amounts. The median concentration of HIVinfected cells in women who suffer from HIV is I per 104 cells. Virus particles found in the cell and non cell component of breast milk. In the study Nduati et al, HIV was found in $58 \%$ of the examination of colostrum and breast milk. The highest level of HIV in breast milk occurs from the first week to three months postpartum. HIV in low concentrations can still be detected up to 9 months after childbirth. The risk of transmission in breastfed children was highest in the first six months, and then decreased gradually in the following months. HIV levels in breast milk are also influenced by maternal serum levels of HIV, CD +4 mothers and deficiency of vitamin A. Semba et al suggested that the levels of HIV in breast milk was higher in mothers whose children were infected with HIV than those who without. A wide variety of other factors, which may increase the risk of HIV transmission through breast milk, among others, on the putting mastitis or breast milk, breast abscesses, oral mucosal lesions in children, prematurity and infant immune response.

The lower the CD4 cell count, the greater the risk of HIV transmission from mother to infant through breast milk. HIV present in breast milk, although there is much smaller concentrations compared to HIV in the blood. Some research suggests that there are several factors that affect the level of risk of HIV transmission through breastfeeding, the age of the baby, sores in the baby's mouth, the high concentration of the virus, the immune status of the mother, duration of breastfeeding and the presence of an abscess or mastitis in the breast or cracked nipples. Results from these studies have compatibility with these studies, that breastfeeding from an infected mother is a risk factor for transmission of HIV infection to the baby. The longer the breastfeeding, the greater the cumulative risk of HIV transmission from mother to baby. In the first 5 months of age predicted breastfeeding transmission risk of $0.7 \%$ per month. Between 6-12 months, the risk of $0.5 \%$ per month, and between 13-24 months, the risk increased again by $0.3 \%$ per month. Miotti, et al on research in Malawi proved Breastfeeding increases the risk of HIV transmission $0.7 \%$ per month at the age of $0-5$ months, $0.6 \%$ in $6-11$ months, and $0.3 \%$ per month at age $12-17$ months. Research in Nairobi comparing children of mothers with HIV are fed with breast milk compared with formula shows the probability of HIV infection at 24 months of $36.7 \%$ compared to $20.5 \%$. However, mortality after two years in both groups was the same. Research Leroy et al, many countries mention the risk of HIV transmission through breast milk is expected is 3.2 per 100 child-years. Thus, shortening the period of breastfeeding is reducing the risk of transmission.

In developed countries, efforts to avoid breast-feeding children from mothers with HIV, as advocated, are not big deal. Unfortunately, it is quite difficult to implementing this in developing countries, due to its limited funds to purchase formula milk, difficult to find clean water and provide clean bottles in addition to the norms that occur in particular society. However, the formula milk is not always more effective than breast milk to prevent transmission of HIV, but depending on how its administration. Research Coutsouidis et al, indicated that children who were exclusively breast milk for 3 months had a lower risk of HIV transmission (14.6\%) compared to children who received formula milk and breast milk (24.1\%) and even had equal risk to formula milk feeding only. This probably occured because of contaminated water and food given to children who received two kinds of milk are damaging the baby's intestines, so HIV from breast milk can get into the baby's body. Because of these things, WHO, UNICEF and UNAIDS give 
recommendations to avoid breast milk infected HIV if other dairy alternatives are available and secure. In children who are HIV-infected in utero, exclusive breastfeeding is recommended unless circumstances do not allow the mother. Maternal disease condition also need to be considered for people who are living with HIV, which is known that mother who breastfeed have a higher risk of death than those who did not breast-feed.

The weakness of this study was there is no record of how long a mother gave breastmilk; There is no record of whether the mother has mastitis, mammary abscess; We did not know the level of mother's viral load and CD4 while breastfed; and whether the baby gets mixed feeding or not.

\section{Conclusion}

Breastfeeding is an important risk factor in HIV transmission from mother to child, when mothers had have no ARV therapy.

\section{References}

[1] Pedoman Pencegahan Penularan HIV dari Ibu ke Anak. Kementerian Kesehatan Republik Indonesia.. Available from: http:// www. depkes.com.

[2] Rencana Aksi Nasional Pencegahan Penularan HIV dari Ibu ke Anak (PPIA) Indonesia 2013-2017. KesehatanRepublik Indonesia. Available from: http:// www.depkes.com.

[3] Guidelines for second generation HIV surveillance: an update: Know your epidemic. Joint United Nations Programme on HIV/ AIDS. World Health Organization. Available from http:// www.who.int.

[4] Situasi HIV/AIDS di Indonesia Tahun 1987-2006. Pusat Data dan Informasi, Departemen Kesehatan R. I. Jakarta, 2006. Available from: http:// www.depkes.com.

[5] Fauci A, Braunwald E, et.al. Human Immunodeficiency Virus Disease. In: Harrison's Principles of Internal Medicine. $17^{\text {th }}$ Edition. United States of America. McGraw-Hill Companies 2008. p. 1-10.

[6] Cunningham FG, Gant NF, Lereno KJ, Gilstrap III LC, Hanth JC, Wenstrom KD. Human Immunodeficiency Virus Infection. In: William's Obstetric. $22^{\text {nd }}$ Edition. New York: Mc GrawHill; 2001. p. 1-8.

[7] Djoerban Z, Djauzi S. HIV/AIDS di Indonesia. Dalam: Buku
Ajar Ilmu Penyakit Dalam. Jilid 3. Edisi 4. Jakarta: Interna Publishing. 2006. Hal.1803-7.

[8] Decherney A, Goodwin M. et.al. Human Immunodeficiency Virus Infection. In: Current Diagnosis and Treatment Obstetrics and Gynecology. 10 ${ }^{\text {th }}$ Edition. United States of America. McGraw-Hill Companies 2007. p. 1-6.

[9] Panduan Tatalaksana Klinis Infeksi HIV pada Orang Dewasa dan Remaja, Edisi Kedua. Departemen Kesehatan R. I. 2007. Available from: http:// www.depkes.com.

[10] HIV classification: CDC and WHO Staging System. HRSA HIV/AIDS Bureau. June 2012. World Health Organization. Available from http:// www. who.int.

[11] Bulterys, M., Ellington S., Kourtis AP. HIV-1 and Breastfeeding: Biology of Transmission and Advances in Prevention. Clin Perinatol 37 (2010) 807-824.

[12] Depkes RI. Pedoman Nasional Pencegahan Penularan HIV dari Ibu ke Bayi, 2006.

[13] WHO. Antiretroviral drug for treating pregnant women and preventing HIV infection in infant in resource - limited setting. HIV/AIDS Programme. Recommendation for a public health approach, 2006 version. Diambil dari: http://www.who.int/hiv/pub/guidelines/pmtctguidelines2.pdf.

[14] Depkes RI. Pedoman Nasional Perawatan, Dukungan dan Pengobatan bagi ODHA, 2003.

[15] Alimonti J, Blake T, Fowke K. Mechanisme of CD4 Tlymphocyte cell death in HIV infection. Journal of General Virology 2003;22:1649-61.

[16] Vertical transmission (cited 2011). www.unaids.org

[17] Djauzi S, Doerban Z. Penatalaksanaan HIV/AIDS di pelayanan kesehatan dasar, Pokdiksus AIDS FKUI/RSCM dan Yayasan Pelita Ilmu, Jakarta, 2003.

[18] Yunihastuti E, Wibowo N, Djauzi S, Djoerban Z. Infeksi HIV pada kehamilan, Fakultas Kedokteran Universitas Indonesia, Jakarta 2003.

[19] Sherr L. Vertical transmission of HIV-pregnancy and infant issues. In: Rohleder P, editor. HIV/AIDS in South Africa 25 Years. Springer Science, New York; 2009: hal. 183-205.

[20] WHO. Strategic approaches to the prevention of HIV infection in children. Report of a WHO meeting, Morges, Switzerland, 2002.

[21] WHO. Infant feeding and HIV transmission. Department of Nutrition for Health and Development, 2005. 